University of Nebraska - Lincoln

DigitalCommons@University of Nebraska - Lincoln

Roman L. Hruska U.S. Meat Animal Research

U.S. Department of Agriculture: Agricultural Center

Research Service, Lincoln, Nebraska

1988

\title{
Growth and Carcass Traits of Heifers as Affected by Hormonal Treatment
}

John D. Crouse

U.S. Meat Animal Research Center

Bruce D. Schanbacher

U.S. Meat Animal Research Center

H. Russell Cross

Texas A \& M University

Steven C. Seideman

Bryan Meats

Stephen B. Smith

Texas A \& M University

Follow this and additional works at: https://digitalcommons.unl.edu/hruskareports

Part of the Animal Sciences Commons

Crouse, John D.; Schanbacher, Bruce D.; Cross, H. Russell; Seideman, Steven C.; and Smith, Stephen B., "Growth and Carcass Traits of Heifers as Affected by Hormonal Treatment" (1988). Roman L. Hruska U.S. Meat Animal Research Center. 88.

https://digitalcommons.unl.edu/hruskareports/88

This Article is brought to you for free and open access by the U.S. Department of Agriculture: Agricultural Research Service, Lincoln, Nebraska at DigitalCommons@University of Nebraska - Lincoln. It has been accepted for inclusion in Roman L. Hruska U.S. Meat Animal Research Center by an authorized administrator of DigitalCommons@University of Nebraska - Lincoln. 


\title{
Growth and Carcass Traits of Heifers as Affected by Hormonal Treatment
}

\author{
John D. Crouse, Bruce D. Schanbacher, H. Russell Cross, Steven C. Seideman, and Stephen B. Smith ${ }^{1,2}$
}

\section{Introduction}

The beef industry traditionally has discriminated against young heifers in the marketplace when compared with steers. Price discrimination was probably the result of sex effects on fat partitioning and distribution. Also, steers have been observed to be more efficient than heifers in the conversion of feed to carcass weight.

Both testes and ovaries secrete steroids that influence performance traits of cattle. Testosterone appears to stimulate rate of gain and efficiency of feed conversion in the male. Efficiencies of conversion of feed to liveanimal weight gains have been less in spayed feedlot heifers than in intact heifers.

It has been suggested that androgens and estrogens are both necessary to realize maximum growth potential. In cattle, the concentration of steroids in blood that results in the fastest growth rates corresponds approximately to a combination of the androgen level in growing bulls and the estrogen level in young heifers. Thus, the optimal treatment should maintain this natural hormone status for as long as possible, preferably several months. If the hypothesis is valid, the greatest benefits would be seen in bulls treated with estrogens, steers treated with an androgen combined with an estrogen, and heifers and cows treated with androgens.

Therefore, the objectives of the investigation were to determine the effects of surgical castration, estradiol immunoneutralization and(or) treatment with an exogenous androgen (trenbolone acetate) on growth, carcass characteristics, and meat palatability of heifers fed in a feedlot.

\section{Procedure}

A total of 77 late-maturing, crossbred heifers (Angus or Hereford dams bred to Simmental) or intermediatematuring crossbred heifers (Hereford $x$ Angus or Angus $x$ Hereford) were randomly assigned within breed type to one of six treatments. Heifers weighed about $440 \mathrm{lb}$ at the initiation of the experiment. Youthful heifers were

'Crouse is the research leader, Meats Unit, and Schanbacher is a research physiologist, Reproduction Unit, MARC; Cross is a professor of animal science, Texas A\&M University (formerly the meats research leader, MARC); Smith is an associate professor of animal science, Texas A\&M University (formerly a research chemist, MARC); and Seideman is employed by Bryan Meats, West Point, Mississippi (formerly a research food technologist, MARC).

${ }^{2}$ The full report of this work was published in J. Anim. Sci. 64:1434-1440, 1987. required to alter hormonal regulation of growth before puberty; therefore, heifers were assigned to treatments before reaching puberty. Animals were fed an $85 \%$ total digestible nutrient (NRC, 1982), $10.5 \%$ crude protein corncorn silage diet supplemented with soybean meal and minerals during the finishing phase of the trial. Feed consumption was recorded and animals were weighed, immunized, and(or) implanted at 56-day intervals.

The following treatments were applied to the heifers: group 1-intact heifer controls (C); group 2-ovariectomized heifers; group 3-intact heifers immunized against estradiol conjugated to bovine serum albumin (BSA-E); group 4-intact heifers immunized as in group 3 plus trenbolone acetate (BSA-E + TBA); group 5 -intact heifers implanted with trenbolone acetate (TBA); and group 6-ovariectomized heifers implanted with trenbolone acetate (OVX + TBA).

\section{Results}

Growth and Performance. Average daily gains (ADG) and quantities of total digestible nutrients (TDN) required per unit of gain for treatments are given in Table 1. Growth and performance treatment means indicate possible results due to treatments, but must be considered tentative because variation among treatment means was not statistically significant. As much as 18 to $22 \%$ of variation between treatment means was observed for $A D G$ and TDN/gain, respectively.

The ADG was similar for the $C$ and OVX groups but tended to be less than for other treatments. The BSA-E + TBA treatment seemed to have the greatest rates of gain of liveweight over the feeding trial, as well as the least required amount of TDN per unit of gain of liveweight. The OVX treatment seemed to require the most feed per unit of gain. Results of research are consistent with previous observations. Spayed heifers fed in the feedlot have not performed comparably to intact heifers.

Heifers implanted with TBA tended to have improved rates of gain and efficiency of gain (Table 1). Because trenbolone-treated heifers also possessed less percentage fat of the rib (Table 2), it could be hypothesized that TDN per unit of gain of protein would be significantly greater in the TBA-treated heifers. The experimental design of the present study did not allow this observation to be made, but TDN per unit of gain of protein should be considered in future experimentation.

Immunoneutralization of endogenous estradiol tended to improve ADG of heifers as compared with control or OVX groups. A trend for improved efficiency of gain also was observed.

Table 1-Growth and performance traits of heifers

\begin{tabular}{|c|c|c|c|c|c|c|c|c|}
\hline \multirow[b]{2}{*}{ Trait } & \multicolumn{6}{|c|}{ Treatment } & \multirow{2}{*}{$\begin{array}{l}\text { Residual } \\
\text { SD }\end{array}$} & \multirow{2}{*}{$\begin{array}{c}\text { Probability } \\
>\mathrm{F}\end{array}$} \\
\hline & Control & ovx & BSA-E & BSA-E + TBA & TBA & OVX-TBA & & \\
\hline No. & 14 & 14 & 10 & 9 & 15 & 15 & & \\
\hline Avg daily gain, Ib & 2.2 & 2.2 & 2.2 & 2.6 & 2.2 & 2.4 & .2 & .36 \\
\hline TDN/gaina & 5.69 & 6.11 & 5.25 & 4.99 & 5.64 & 5.57 & .38 & .25 \\
\hline
\end{tabular}


Carcass Characteristics. Muscle characteristics evaluated at the 12th rib interface, color, firmness, texture, and maturity were similar among treatment groups. Treatment of heifers with the androgenic hormone TBA did not produce dark-colored meat that has been observed in meat obtained from intact males. Ovariectomy or immunization also had no effect on color or textural characteristics of the lean.

Heifers treated with TBA tended to possess less fat cover, and the OVX-TBA group possessed less fat cover over the 12th rib than the other three groups (Table 2). Trenbolone-treated heifers also possessed less percent fat in the soft tissue of the 9-10-11th rib section than the control group.

Marbling scores did not vary among treatment groups and did not reflect the variation in deposition of rib fat associated with OVX and TBA treatments (Table 2). Observations indicate that TBA may be effective in reducing fat cover of carcasses without decreasing marbling content. Various fat depot sites apparently respond differently to the influences of TBA.
Sensory and Textural Characteristics. Sensory and textural properties of ribeye steaks are given in Table 3. Treatments had no effects on sensory characteristics. Tenderness scores for TBA treatments were very similar to those of the $\mathrm{C}$ group. Shear force values also were similar among treatment groups. Therefore, the use of the androgenic hormone, TBA, did not decrease meat tenderness, as commonly observed in meat obtained from intact male cattle. Sensory panel scores for ease of fragmentation and amount of connective tissue support conclusions of overall tenderness values.

\section{Conclusion}

Combined BSA-E and TBA tended to be superior to either treatment alone for efficiency of gain and rate of gain. The combined treatment also tended to produce carcasses with greater ribeye areas. Future studies should consider muscle mass or protein deposition per unit of feed as a measure of efficiency. Treatment with androgenic hormone (TBA) was effective in reducing fat deposition and increasing muscle mass. Improvement in growth and carcass characteristics was not associated with a change in meat sensory characteristics.

Table 2-Carcass traits of heifers by treatments adjusted to constant carcass weight

\begin{tabular}{|c|c|c|c|c|c|c|c|c|}
\hline \multirow[b]{2}{*}{ Trait } & \multicolumn{6}{|c|}{ Treatment } & \multirow{2}{*}{$\begin{array}{l}\text { Residual } \\
\text { SD }\end{array}$} & \multirow{2}{*}{$\begin{array}{c}\text { Probability } \\
>\mathrm{F}\end{array}$} \\
\hline & Control & ovx & BSA-E & $B S A \cdot E+T B A$ & TBA & OVX-TBA & & \\
\hline Live wt, Ib & 951 & 956 & 954 & 958 & 945 & 958 & 22 & .68 \\
\hline Lean colora & 5.34 & 5.31 & 5.68 & 5.61 & 5.37 & 5.69 & .70 & .60 \\
\hline Firmness ${ }^{b}$ & 5.13 & 4.94 & 5.34 & 5.81 & 5.31 & 5.18 & .76 & .32 \\
\hline Texturec & 4.86 & 5.07 & 5.18 & 5.18 & 5.02 & 5.24 & .90 & .92 \\
\hline Maturityd & 144 & 141 & 138 & 144 & 141 & 141 & 7 & .32 \\
\hline Marblinge & 464 & 443 & 445 & 473 & 470 & 438 & 116 & .96 \\
\hline $\begin{array}{l}\text { Adjusted fat } \\
\text { thickness, in } \\
\text { Longissimus muscle }\end{array}$ & $.53 \mathrm{~g}$ & .459 & .539 & .439 & $.42 \mathrm{gh}$ & $.34^{\mathrm{h}}$ & .12 & .01 \\
\hline area, in ${ }^{2}$ & $11.1 \mathrm{~g}$ & 10.8 & $10.5 \mathrm{~g}$ & $11.6^{\mathrm{h}}$ & $11.7^{\mathrm{h}}$ & $11.0 \mathrm{~g}$ & .87 & .02 \\
\hline $\mathrm{K}, \mathrm{P}$, and $\mathrm{H}$ fat, $\% \mathrm{f}$ & 3.16 & 3.08 & 3.33 & 3.09 & 3.09 & 3.09 & .32 & .47 \\
\hline Moisture of rib, \% & $41.1^{i}$ & $42.4^{h}$ & $40.5^{i}$ & 44.1ghi & $45.7 \mathrm{~g}$ & $44.5 \mathrm{gh}$ & 2.6 & .01 \\
\hline Fat of rib, $\%$ & $45.7 \mathrm{gh}$ & 43.9ghi & 46.58ghi & 41.8ghij & $39.8^{i j}$ & $41.1^{i j}$ & 3.5 & .01 \\
\hline
\end{tabular}

aScored: 1 = dark red to 8 = light cherry red.

bscored: $1=$ very soft to $8=$ very firm.

'Scored: $1=$ very coarse to $8=$ very fine.

đScored: 100 to $199=\mathrm{A}$.

eScored: 300 to $399=$ small; 400 to $499=$ modest.

tPercent kidney, pelvic, and heart fat.

ghilimeans in the same line without a common superscript differ $(P<.05)$.

Table 3-Sensory and textural characteristics of steaks for each treatment adjusted to a constant carcass weight

\begin{tabular}{|c|c|c|c|c|c|c|c|c|}
\hline \multirow[b]{2}{*}{ Trait } & \multicolumn{6}{|c|}{ Treatment } & \multirow{2}{*}{$\begin{array}{l}\text { Residual } \\
\text { SD }\end{array}$} & \multirow{2}{*}{$\begin{array}{c}\text { Probabilit } \\
>\mathrm{F}\end{array}$} \\
\hline & Control & ovx & BSA-E & $B S A-E+T B A$ & TBA & OVX-TBA & & \\
\hline Juicinessa & 5.32 & 5.25 & 5.49 & 5.52 & 5.39 & 5.34 & .27 & .32 \\
\hline $\begin{array}{l}\text { Ease of fragmentationa } \\
\text { Amount of }\end{array}$ & 5.33 & 5.20 & 5.43 & 5.40 & 5.30 & 5.32 & .34 & .75 \\
\hline connective tissuea & 5.33 & 5.20 & 5.42 & 5.38 & 5.28 & 5.31 & .35 & .79 \\
\hline Overall tendernessa & 5.35 & 5.21 & 5.42 & 5.40 & 5.30 & 5.33 & .34 & .78 \\
\hline Flavor intensitya & 5.15 & 5.21 & 5.19 & 5.08 & 5.13 & 5.16 & .14 & .42 \\
\hline Shear force, Ib & 12.00 & 12.26 & 12.00 & 11.70 & 11.83 & 11.39 & 3.08 & .71 \\
\hline
\end{tabular}

